\title{
미국의 ODA 현황
}

\section{I . 대외원조(ODA)법 제정여부에 관한 사항}

ㅁ관련법이 있을 경우, 유상 및 무상원조를 포괄하는 법인지 유상 또는 무상원조만을 대상으로 하는 법 인지 여부

- 미국 정부에는 전반적인 공적개발원조(ODA)법 이 없으며 별도의 ODA 예산도 없는 바, 1961년 대외원조법(FAA:Foreign Assistance Act of 1961)이 미국의 대외원조 시행관련 제반 법적요 건(statutory requirement)을 포괄하고 있어, 미국의 개발원조의 근거가 되는 가장 중요한 법 이라고 할 수 있으며 이법은 매년 수정되고 있음.

-상기 외에 중요한 법으로 Foreign Affairs Reform and Restructuring Act of 1998가 있 는데대외원조의 이행관련 국내적 조직문제 및 예산에 관한 것이며 그외 Agricultural Trade and Development Act of 1958이 있는 바, 이
는 주로 식량원조 및 농업서비스에 관한 것임. ※USAID는 1961년 대통령의 행정명령(Executive order)에 의해 설립되었을 당시에는 행정명령은 필 요시 언제든지 철회될 수 있다는 점에서 temporary agency였으나, 상기 1998년 Act로 인해 상설적인 조직이 되었음.

-상기 외 International Development Cooperation Act of 1979 가 있었으나 폐지되었음. -상기 법들은 개발지원만을 규정하고 있는 것은 아니지만 동 법들에 포함되어 있는 대외원조에 관한 것은 모두 무상원조에 관한 것임.

\section{II . 대외원조 시행기관 관련사항}

ㅁ유상원조 및 무상원조 담당기관이 일원화되어 있 는지 또는 각각 별도의 조직으로 되어 있는지 여부 - 미국이 시행하는 무상원조의 경우, USAID가 가 
장 중요한 기관이라고 할 수 있으나 개발원조는 국무부, 재무부, 농무부, 국방부, 평화봉사단 등 50 여개의 정부부처 또는 기관이 담당하고 있음 (유상원조는 아래에서 설명).

\section{III. 기타 사항}

밈국은 대외원조에서 총액기준 무상원조가 $99 \%$ 이상을 차지하는 바, 유상원조(soft loan)의 경우, Title 1 Food Aid Loan이라는 명칭으로 미 농무부 에서 시행하는 한 가지 프로그램 밖에 없으며 이는 $\mathrm{PL}$ (Public Law) 480을 법적 근거로 하고 있음.

-미국 정부는 유상원조보다 무상원조가 바람직 하다는 인식 하에서 60 년대부터 유상원조를 점 진적으로 감소시켜 왔음.

무상원조 시행기관이 분산되어 있을 경우, 전담기 관과 여타 기관 간의 사업 비중

-USAID가 미국 ODA의 약 50\% 정도를 담당, 여타 기관이 나머지 $50 \%$ 를 담당하며 USAID는 양자지원의 $75 \%$ 정도를 담당함(미국 무상지원 의 경우, 다자지원이 $22 \%$ 정도, 나머지가 양자 지원).

-Millennium Challenge Account가 설치된 이
후 상기 USAID가 미국 $\mathrm{ODA}$ 에서 차지하는 비 중은 $50 \%$ 조금 못 미치는 수준으로 하락하였음. 대외무상원조사업을 다수의 부처(기관)이 수행시 조정기능 여부

-조정문제와 관련, FAA of 1961에 근거하여 대 통령 산하 NSC(National Security Council)가 적극적인 역할을 하고 있으며 NSC가 조정역할 을 하기 어려울 경우에는 사안에 따라 USAID, 재무부, 국무부 등 다른 기관이 조정역할을 하도 록 역할을 위임(delegate)함.

- 이러한 조정은 FAA of 1961에 근거하여 설치되 는 다양한 위원회 개최를 통해 이루어지며(동 위 원회에 각종 관계부처들이 참석), G-8 정상회의 또는 유엔총회에 대비한 Working Group 구성 등을 통해 조정하기도 함.

ㅁ해외긴급재난 발생시 자국민 또는 피해국에 대한 지원체제와 관련된 법령 유무

- 해외긴급재난 발생시에 대비한 기금으로 US Emergency Fund for Complex Foreign Crisis 및 International Disaster and Famine Assistance(IDFA)가 있는 바, 근거 법령은 상 기 FAA of 1961이며 USAID 예산에 포함되어 운영되고 있음.

[자료:주미 대사관] 